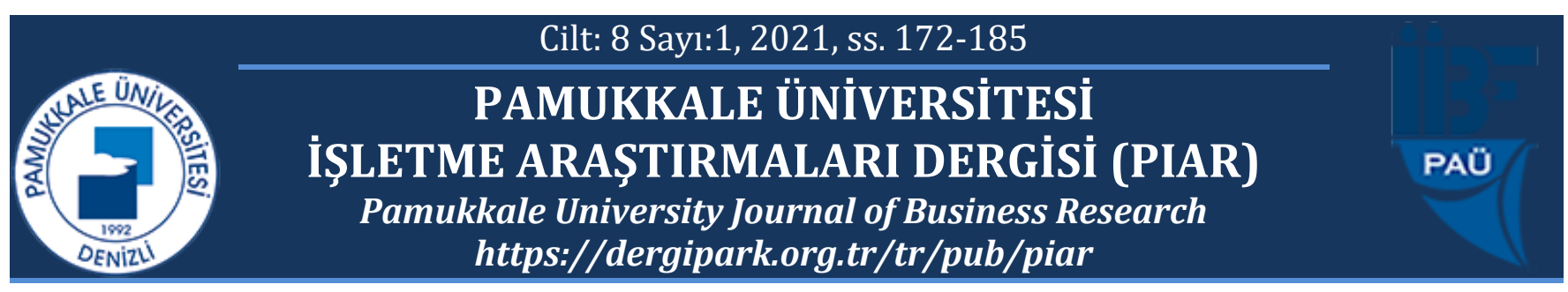

\title{
İmalat İşletmelerinin İnovasyon Kapasitesi: Denizli İli Örneği ${ }^{* *}$
}

\section{Innovation Capacity of Manufacturing Enterprises: The Sample of Denizli Province*}

\author{
Halil SAVAŞ ${ }^{*} \quad$ Hatice TÜKEN ${ }^{2}$
}

\begin{abstract}
${ }^{1}$ Pamukkale Üniversitesi, İ.İB.F., İşletme Bölümü, hsavas@pau.edu.tr , https://orcid.org/0000-0001-7942-5527
2 Pamukkale Üniversitesi, S.B.E., htuken09@pau.edu.tr, https://orcid.org/0000-0002-3809-4802

* Yazışılan Yazar/Corresponding author
\end{abstract}

\section{Öz}

Bir işletmenin inovasyon kapasitesi, işletmenin stratejilerinin uygulanmasinda ve elde ettiği rekabet avantajinn sürdürebilir olmasında oldukça önemlidir. Bu çalışmanın amacı, işletmeler açısından inovasyonun ve inovasyon kapasitesinin önemini vurgulamak ve piyasada aktif olarak faaliyet gösteren imalat işletmelerinin inovasyon kapasitesini belirlemektir. Araştırma, Denizli ilinde faaliyette bulunan imalat işletmelerinin inovasyon kapasiteleri üzerine yapılmıştır. Literatür taraması ve kuruluşlarla bilgi alışverişi neticesinde oluşturulan anket çalışması ile Pamukkale ve Merkezefendi ilçelerinde faaliyette bulunan 55 imalat işletmesinden veriler elde edilmiş ve analize tabi tutulmuştur. Ilk olarak SPSS 21.0 ile bu verilerin güvenilirlik ve geçerlilik analizleri yapılmıştır. Demografik özelliklere göre elde edilen veriler ve anket çalışmasında ulaşılan cevaplar ayr ayru incelenmiştir. Daha sonra imalat işletmelerinin inovasyon kapasitesi bileşenlerinin aralarındaki ilişkinin anlamlı olup olmadığ ve ne yönde olduğunu tespit etmek amacıyla Spearman Korelasyon analizi yapılmıştır. Analiz çalı̧masının ardından hipotezlerin test edilmesi için Kruskall-Wallis ve Mann Whitney $U$ testleri uygulanmıştır. Hipotez testlerinin sonucuna göre; "İmalat işletmelerinin inovasyon kapasitesi bileşenleri ile imalat işletmelerinin faaliyet alanları arasinda anlaml bir farkllik vardir" hipotezi reddedilmiş, "Imalat işletmelerinin inovasyon kapasitesi bileşenleri ile imalat işletmelerinde istihdam edilen personel sayıları arasinda anlaml bir farklllk vardı" hipotezi kabul edilmiştir.

Anahtar kelimeler: İnovasyon, Inovasyon Kapasitesi, Imalat İşletmeleri.

JEL kodları: C42, D24, M11, O32

\begin{abstract}
The innovation capacity of an enterprise is crucial in the implementation of the enterprise's strategies and the sustainability of the competitive advantage it has achieved. The aim of this study is to emphasize the significance of innovation and innovation capacity in terms of enterprises and to determine the innovation capacity of manufacturing enterprises that are actively operating in the market. The research was conducted on the innovation capacities of the manufacturing enterprises in the Denizli province. With the survey study which was created as a result of literature review and information exchange with organizations, data from 55 manufacturing enterprises operating in Pamukkale and Merkezefendi districts were obtained and analyzed. Firstly, the analysis of reliability and validity of these data were completed with the SPSS 21.0. The data which are obtained based on demographic characteristics and the responses obtained from the questionnaire study were examined individually. Then, a Spearman correlation analysis was conducted to determine whether the relationship between the components of the innovation capacity of the manufacturing business is meaningful or not and define the direction of this relationship. Following the analysis step the Kruskal-Wallis and Man Whitney $U$ tests were applied to test the hypotheses. According to results of the hypothesis tests, the hypothesis of "There is a meaningful difference between the components of innovation capacity of manufacturing businesses and operating fields of manufacturing business" has been rejected and the hypothesis of "there is a meaningful difference between the components of innovation capacity of manufacturing businesses and the number of personnel employed in manufacturing businesses" has been accepted.
\end{abstract}

Keywords: Innovation, Innovation Capacity, Manufacturing Enterprises.

JEL codes: C42, D24, M11, O32

\footnotetext{
* Bu çalışma, Hatice TÜKEN'in "İmalat İşletmelerinin İnovasyon Kapasitesi: Denizli İli Örneği” başlıklı Yüksek Lisans Tezi'nden türetilmiştir.
} 


\section{GİRIŞ}

Hızla değişen ve gelişen dünya şartlarında, işletmelerin varlıklarını devam ettirebilmeleri ve piyasadaki güçlerini artırabilmeleri için kendilerini sürekli olarak gözden geçirmeleri ve yenilemeleri gerekmektedir. Şirketlerin ürünlerini, hizmetlerini ve üretim yöntemlerini sürekli olarak değiştirme ve yenileme işlemi inovasyon kavramı adı altında incelenmektedir. İnovasyon kavramı, Latince "innovatus" kelimesinden türemiştir ve yenilik, yenilenme, yenilikçilik anlamına gelmektedir. Günümüzde önemli bir rekabet aracı ve performans göstergesi haline gelen inovasyon kavramını, çeşitli tanımlamalarla açıklamak mümkündür.

OECD ve $A B$ literatüründe inovasyon kavramı: Bir yenilik, işletme içi uygulamalarda, işyeri organizasyonunda veya dış ilişkilerde yeni veya önemli derecede iyileştirilmiş bir ürün (mal veya hizmet), veya süreç, yeni bir pazarlama yöntemi ya da yeni bir organizasyonel yöntemin gerçekleştirilmesidir (OECD/Avrupa Birliği, Oslo Kılavuzu, 2005: 50).

Peter Drucker'a göre inovasyon girişimciliğin bir fonksiyonudur. İnovasyon, girişimcinin ya yeni kaynaklar üreterek refah yaratması ya da mevcut kaynakların kullanım potansiyelini artırarak refah yaratmasıdır (Drucker, 1998: 149).

Porter inovasyonun rekabet avantajı sağlayan yeni teknolojileri ve yeni iş yapma yöntemlerini içerdiğini söylemiştir. Rogers inovasyonu kişilerin yeni olarak algıladığı fikir, uygulama ya da nesne şeklinde tanımlamıştır. Damanpour ise inovasyonu bir firmanın başarısı üzerinde yeni düşüncelerin uyumu, yeni fikirlerin geliştirilmesi ve oluşturulması olarak ifade etmiştir. Trott inovasyonu bir yönetim süreci olarak görmüş ve inovasyonu düşünce oluşturma, teknoloji geliştirme, yeni ya da iyileştirilmiş bir ürünün, hizmetin ya da imalat sürecinin meydana getirilmesi ve pazarlama süreci faaliyetlerinin yönetilmesi olarak yorumlamıştır (Ecevitsatı ve Özlem, 2011: 540).

Elçi'ye göre inovasyon; ekonomik ve toplumsal değer yaratmak için ürünlerde, hizmetlerde ve iş yapış yöntemlerinde yapılan değişiklik, farklılık ve yeniliklerdir (Elçi, 2006: 2).

Başka bir tanıma göre inovasyon; bilginin veya fikrin piyasaya sunularak veya satışları artırma ve maliyetleri azaltma yoluyla karı artırarak ticarileştirilmesi, uygulanması, ürün, hizmet ve sürece dönüştürülmesi veya mevcut ürün, sistem ve kaynakların değiştirilmesidir (Naktiyok, 2007: 213).

İşletmeler için inovasyon, verimliliği ve karlılığı arttırdığı ve yeni pazarlara kolaylıkla girilmesini ve mevcut pazarın büyütülmesini sağladığı için oldukça önemli bir rekabet aracıdır. İşletmelerin inovasyon faaliyetlerini etkin bir şekilde yürütebilmeleri için inovasyonu kabul eden ve bu konu ile ilgili gerekli teşviklerde bulunan bir örgüt kültürüne sahip olmaları gereklidir. İnovatif fikirlere açık bir kültüre sahip olan işletmelerin inovasyon stratejilerini kendi organizasyonel yapılarıyla uyumlu hale getirmeleri ve inovasyon sürecine yönetsel anlamda destek sağlamaları gerekmektedir (Ecevitsatı ve Özlem, 2011: 541).

Bir firmanın inovasyon kapasitesi yani inovasyon yapabilme yeteneği, firmanın sahip olduğu stratejilerin uygulanmasında ve rekabet avantajı elde etme ve bunu sürdürebilme konularında oldukça önemlidir. Bu nedenle inovasyon kapasitesi bir firmanın sahip olduğu önemli ve özel bir varlıktır. Lawrence ve Lorsch, Prahalad ve Hamel, Kogut ve Zander gibi yazarlar, inovasyon kapasitesini rekabet için bir anahtar olarak görmektedirler (Akman ve Y1lmaz, 2008: 78-79). 
Adler ve Shenbar' a göre inovasyon yapabilme yeteneği yani inovasyon kapasitesi şu şekilde tanımlanmaktadır (Akman ve Yılmaz, 2008: 79): Piyasanın ihtiyaçlarını karşılayan yeni ürün geliştirme kapasitesi, bu yeni ürünleri üretmek için uygun işlem/süreç teknolojilerinin uygulanması kapasitesi, gelecekteki ihtiyaçları karşılamak için yeni ürün ve işleme teknolojileri geliştirme ve benimseme kapasitesi, değişen teknoloji faaliyetlerine yanıt verme kapasitesi ve rakiplerin ortaya çıkardığı beklenmedik fırsatlar.

İnovasyon kapasitesi ile ilgili olarak birçok tanımlama ve açıklama mevcuttur. Bazı yazarlara göre inovasyon kapasitesi tanımları ve açılamaları şu şekildedir (Roman, 2011: 461- 462):

Calantone'a göre inovasyon kapasitesi, firmanın yenilikçilik derecesi şeklinde ifade edilmiştir. Firmanın yenilikçiliği ise, yeni fikirlerin üretilmesi, yeniliği meydana çıkarmak için yeni yollar arama, operasyon yöntemlerinde yaratıcılığın ön plana çıkması, piyasada lider konumuna gelme, risk alma gibi konularla yakından ilgilidir.

Elmquist ve Le Masson'a göre inovasyon kapasitesi, pazar fırsatlarından yararlanmak için yeni fikir ve bilgi üretmektir. Bunun için Ar-Ge projelerinin inovasyon kapasitesine katkısı, finansal kaynaklar, firmanın stratejik vizyonu, yeterlilikleri ve bilgi boşlukları gibi konularda ölçümler yapılır.

Nassimbeni' ye göre ürün ve süreçlerde yeniliklerin meydana getirilmesi inovasyon kapasitesini ifade eder.

Neely ve diğerlerine göre inovasyon yapabilme kapasitesi, inovasyon kültürü, işletme içerisindeki süreçlerde inovasyon yapabilme yeteneği ve dış çevreyi anlayabilme yeteneği ile ilgilidir. Bunun için inovasyonu teşvik eden ve destekleyen bir şirket kültürünün var olması, çalışanlarla iş birliği içinde ve bilgi paylaşımında bulunulması ve teknolojinin ve piyasanın iyi bir şekilde takip edilmesi gereklidir.

Zhao' ya göre inovasyon kapasitesi şu maddelerden oluşur: Firmanın patent sahibi olması gibi fikri mülkiyet şeklinde bilgi üretme becerisi. Belli bir piyasa değeri elde edilinceye kadar inovasyonla ilgili bilgilerin uygulanması. Organizasyonda yaratıcı fikirlerin başarılı bir şekilde uygulanması.

İnovasyon kapasitesi gelişmekte olan ülkelerde işletmelerin faaliyetlerinin sınıflandırılması için oldukça önemlidir. Bir işletmenin inovasyon kapasitesi; esas olarak o işletmenin pazar fırsatlarından yararlanmasını sağlayan tüm unsurlardır. İnovasyon kapasitesini oluşturan etkenler, esas olarak insan kaynaklarında saklı bulunmaktadır. Aynı zamanda işletmelerin prosedürlerinde, rutin işlerinde ve diğer özelliklerinde de mevcut olan, işletme tarafından biriktirilen bilgilerde inovasyon kapasitesini oluşturan etkenlerdir. OECD Klavuzu'na göre işletmelerin inovasyon kapasitelerinin ölçümünde bazı boyutlar vurgulanmaktadır. $\mathrm{Bu}$ boyutlar; İnsan Kaynakları, Bağlantılar, Bilgi ve İletişim Teknolojileri 'dir (OECD/Avrupa Birliği, Oslo Kılavuzu, 2005: 143-144).

Karaveg' e göre inovasyon kapasitesi işletmelerin piyasada iyi bir rekabet avantaj1 elde edebilmek, sürdürebilirliğini ve büyümesini garanti altına alabilmek ve tercih edilebilirlik cazibesini artırmak maksadıyla gerçekleştirilen faaliyetler olarak kabul edilmektedir. Bilgi ve teknolojiyi inovasyona dönüştürme, bir organizasyonun Ar-Ge çalışmalarında ve ürün geliştirme süreçlerinde profesyonel olmasını sağlama, üretim süreçlerinde verimliliği artırma açısından teknolojik inovasyon yapma, çevresel inovasyon yapma ve yönetsel açıdan 
inovasyon yeterliliğine sahip olma kavramları inovasyon kapasitesi konusunda ele alınmaktadır (Karaveg, 2013: 37-39).

İnovasyonun kapasitesinin firma büyüklüğü ile de bir ilişkisi bulunmaktadır. Nitekim, yapılan birçok çalışma, firma büyüklügünü inovasyonun anahtar bir değişkeni olarak tanımlamakta ve firmanın büyük ölçekli bir firma olması ile inovasyon kapasitesi arasında direkt bir ilişki bulunduğunu belirtmektedir (Martino ve Magnotti, 2017: 362-383).

İnovasyon kapasitesi bileşenlerini “İnovasyon Kapasitesi İndeksi” ise şu şekilde belirlemiştir. (1) Kurumsal Çevre, (2) Beşeri Sermaye, Eğitim ve Sosyal Hakların İçeriği, (3) Düzenleyici ve Yasal Çerçeve, (4) Araştırma-Geliştirme, (5) Bilgi ve İletişim Teknolojilerinin Benimsenmesi ve Kullanılması (Lopez-Claros ve Mata, 2010: 20).

Sonuç olarak; inovasyon kapasitesinin bileşenleri birçok yazar tarafından farklı şekillerde sıralanmış ve farklı başlıklar altında incelenmiştir. Yapılan literatür taraması neticesinde bu çalışma kapsamında inovasyon kapasitesi bileşenleri altı başlık altında incelenecektir. Bunlar; Ar-Ge Faaliyetleri, İnsan Kaynakları Yatırımları, İş Birlikleri, Bilgi İletişim Teknolojileri, Fikri Mülkiyet Hakları ve İnovasyon Finansmanı sırası ile ele alınmıştır.

\section{METODOLOJI}

\subsection{Araştırmanın Amacı, Kapsamı ve Yöntemi}

Küreselleşmenin hızlandığı pazarlarda faaliyette bulunan işletmelerin rekabet güçlerini ve karlılıklarını artırabilmeleri, işletme içerisinde inovasyon faaliyetlerini etkin bir şekilde gerçekleştirmelerine ve inovasyon kapasitelerini doğru olarak kullanabilmelerine bağlıdır. $\mathrm{Bu}$ çalışmanın amacı, Denizli ilinde faaliyet gösteren imalat işletmelerinin inovasyon kapasitelerinin araştırılmasıdır. Bir işletmenin inovasyon kapasitesi üzerinde etkili olan unsurlar altı başlıkla ele alınmıştır. Araştırma kapsamında bu altı başlık dikkate alınarak imalat işletmeleri üzerinde incelemelerde bulunulmuştur.

Denizli ilinde faaliyette bulunan imalat işletmeleri üzerinde gerçekleştirilen anket çalışması ile veri elde edilmeye çalışılmıştır. Anket formunun ilk sayfasında anketi cevaplayana ilişkin bilgileri ve genel işletme bilgilerini elde etmeye yönelik sorulara yer verilmiştir. Anketin geri kalan kısmı imalat işletmelerinin inovasyon kapasitelerini ortaya çıkarmak adına sorulan sorulardan oluşmaktadır. Anket formu vasıtasıyla bilgi toplama yöntemine dayanan bu çalışmada, Denizli ilinin Pamukkale ve Merkezefendi ilçelerinde faaliyette bulunan imalat işletmelerinin inovasyon girişimleri esas alınmıştır. Bu bağlamda işletmelerin \%94'ü ile yüz yüze görüşme yöntemi tercih edilmiştir. İşletmelerin tercihi üzerine \%6'sı ile mail yoluyla iletişime geçilmiştir. Çalışmayı gerçekleştirmek üzere 96 işletmeye başvurulmuştur. İşletmelerin 24 tanesi anket uygulamayı kabul etmemiş, 9 tanesine ilgili adreste ulaşılamamış, 8 işletmeye mail yolu ile anket ulaştırılmış, ancak geri dönüş sağlanamamıştır. Nihai olarak 55 tane anket formu geçerli kabul edilerek analize tabi tutulmuştur. Anket formu aktif olarak faaliyet gösteren 96 işletmeden 55 işletmeye uygulanabildiği için elde edilen sonuçlar, ilgili işletmelerden alınan verilerle sınırlıdır.

\subsection{Araştırmanın Hipotezleri}

Araştırmanın amacı doğrultusunda belirlenen ve incelenen araştırma hipotezleri şu şekildedir: 
H1: İmalat işletmelerinin inovasyon kapasitesi bileşenleri ile imalat işletmelerinin faaliyet alanları arasında anlamlı bir farklılık vardır.

H2: İmalat işletmelerinin inovasyon kapasitesi bileşenleri ile imalat işletmelerinde istihdam edilen personel sayıları arasında anlamlı bir farklılık vardır.

\subsection{Verilerin Analizi}

Araştırmadan elde edilen verilerin değerlendirilmesinde SPSS 21.0 (Statistical Packages for Social Science) paket programı kullanılmıştır. Verilerin değerlendirilmesinde temel bileşenler analizi, Kolmogorow-Simirov ve Shaphiro-Wilk testi, frekans analizi, Spearman Korelasyon analizi, Kruskall-Wallis ve Mann-Whitney U testleri kullanılmıştır. Araştırma bileşenlerinin güvenilirliği Cronbach Alpha değeri ile araştırılmıştır. Anket uygulaması sonucu elde edilen verilerin ölçek güvenilirliği 0,79 olarak bulunmuştur. Bu değer çalışmaya devam edilebilmesi için yeterli görülmüştür.

\subsection{Araştırma Bulguları}

Anketi cevaplayan kişilere ilişkin özellikler Tablo 1'de gösterilmektedir.

Tablo 1. Anketi Cevaplayan Kişilere İlişkin Özellikler

\begin{tabular}{|l|c|c|}
\hline Cinsiyeti & Kişi & $\mathbf{\%}$ \\
\hline Kadın & 16 & $\mathbf{2 9 , 1}$ \\
Erkek & 39 & 70,9 \\
\hline Yaş Aralı̆̆ı & Kişi & $\mathbf{\%}$ \\
\hline 25 yaş ve altı & 1 & 1,8 \\
26-35 yaş arası & 26 & 47,3 \\
36-45 yaş arası & 21 & 38,2 \\
46-55 yaş arası & 7 & 12,7 \\
56 yaş ve üzeri & - & - \\
\hline Ĕgitim Düzeyi & Kişi & $\mathbf{\%}$ \\
\hline İlköğretim/Ortaöğretim & 5 & 9,1 \\
Lise & 9 & 16,3 \\
Ön Lisans & 5 & 9,1 \\
Lisans & 32 & 58,2 \\
Lisansüstü & 4 & 7,3 \\
\hline
\end{tabular}

\begin{tabular}{|l|c|r|}
\hline Sektördeki Deneyim Süresi & Kişi & \multicolumn{1}{c|}{$\%$} \\
\hline 5 yıl ve daha az & 17 & 30,9 \\
6-10 y1l arası & 12 & 21,8 \\
11-15 yıl arası & 5 & 9,1 \\
16-20 y1l arası & 9 & 16,4 \\
21 yıl ve daha fazla & 12 & 21,8 \\
\hline
\end{tabular}

Tablo 1 incelendiğinde; katılımcıların \%70,9'unun erkek, \%29,1'inin kadın olduğu görülmektedir. Anketi cevaplayanların yarıya yakını $(\% 47,3)$ 26-35 yaş aralığında yer almaktadır. Bu oranı \%38,2 ile 36-45 yaş aralığında yer alanlar takip etmektedir. Katılımcıların \%74,6'sının yüksek öğrenim derecesine sahip olduğu, \%9,1 ile ön lisans, \%58,2 ile lisans ve $\% 7,3$ ile lisansüstü verilerinden anlaşılmaktadır. Katılımcıların \%30,9'unun 5 yıl ve daha az süreli sektörel deneyime sahip olduğu görülmektedir. Bu değeri \%21,8 oranları ile 6-10 yıl arası ve 21 yıl ve daha fazla sektörel deneyime sahip katılımcılar takip etmektedir. Anketi cevaplayan kişilerin \%36,4 oranı ile departman yöneticisi/departman şefi olduğu görülmektedir. Ayrıca bu oranı \%20,0 oranları ile sahip ve yönetici ve işletme müdürü/işletme müdür yardımcısı izlemektedir.

Ankete katılan işletmelerle ilgili elde edilen veriler Tablo 2' de yer almaktadır.

Tablo 2. Ankete Katılan İşletmelere İlişkin Özellikler 


\begin{tabular}{|c|c|c|c|c|c|c|}
\hline Faaliyet Süresi & Sayı & $\%$ & \multicolumn{2}{|l|}{ Hukuki Statüsü } & Say1 & $\%$ \\
\hline 10 yıl ve daha az & 15 & 27,3 & \multicolumn{2}{|l|}{ Anonim Şirket } & 28 & 50,9 \\
\hline 11-15 y1l arası & 5 & 9,1 & \multicolumn{2}{|l|}{ Limited Şirket } & 25 & 45,5 \\
\hline $16-20$ yıl arası & 4 & 7,3 & \multicolumn{2}{|l|}{ Komandit Şirket } & - & \\
\hline $21-25$ y1l arası & 11 & 20,0 & \multicolumn{2}{|l|}{ Şahıs Şirketi } & 2 & 3,6 \\
\hline 25 y1l ve daha fazla & 20 & 36,3 & \multicolumn{2}{|l|}{ 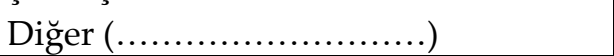 } & - & \\
\hline Faaliyet Alanı & Say1 & $\%$ & \multicolumn{2}{|l|}{ İstihdam Edilen Per. Sayısı } & Say1 & $\%$ \\
\hline Tekstil & 25 & 45,5 & \multicolumn{2}{|l|}{50 kiși ve daha az } & 15 & 27,3 \\
\hline Makine & 8 & 14,5 & \multicolumn{2}{|l|}{ 51-150 kişi arası } & 21 & 38,1 \\
\hline Mermer & 5 & 9,1 & \multicolumn{2}{|l|}{ 151-250 kişi arası } & 4 & 7,3 \\
\hline Kablo & 5 & 9,1 & \multicolumn{2}{|l|}{251 kişi ve daha fazlası } & 15 & 27,3 \\
\hline Metal & 8 & 14,5 & \multicolumn{2}{|l|}{ İhracat Durumu } & Say1 & $\%$ \\
\hline Kimya & 4 & 7,3 & \multirow{2}{*}{\multicolumn{2}{|c|}{$\begin{array}{l}\text { İhracat yapiyor } \\
\text { İhracat yapmıyor }\end{array}$}} & 48 & 87,3 \\
\hline Diğer $(\ldots \ldots \ldots \ldots \ldots)$ & - & - & & & 7 & 12,7 \\
\hline \multicolumn{7}{|c|}{ İhracat faaliyetinde bulunduğu ülke/ülkeler } \\
\hline & Say1 & $\%$ & & Say1 & \multicolumn{2}{|c|}{$\%$} \\
\hline AB Üyesi Ülkeler & $39 / 55$ & 70,9 & Uzak Doğu Ülkeleri & $9 / 55$ & \multicolumn{2}{|c|}{16,4} \\
\hline Diğer Avrupa Ülkeleri & $24 / 55$ & 43,6 & $\mathrm{ABD}$ & $21 / 55$ & \multicolumn{2}{|c|}{38,2} \\
\hline Ortadoğu Ülkeleri & $28 / 55$ & 50,9 & Rusya & $15 / 55$ & \multicolumn{2}{|c|}{27,3} \\
\hline Orta Asya Türk C. & $14 / 55$ & 25,5 & Diğer $(\ldots \ldots \ldots \ldots \ldots \ldots)$ & $11 / 55$ & \multicolumn{2}{|c|}{20,0} \\
\hline \multicolumn{7}{|c|}{ İhracat faaliyetlerinin yıllık toplam satışlara oranı } \\
\hline & Say1 & $\%$ & & Say1 & \multicolumn{2}{|c|}{$\%$} \\
\hline$\% 0$ & 7 & 12,7 & $\% 51-75$ & 18 & \multicolumn{2}{|c|}{32,7} \\
\hline$\% 1-25$ & 9 & 16,4 & $\% 76-100$ & 14 & \multicolumn{2}{|c|}{25,5} \\
\hline$\% 26-50$ & 7 & 12,7 & Toplam & 55 & \multicolumn{2}{|c|}{100} \\
\hline
\end{tabular}

Tablo 2 incelendiğinde; araştırmaya katılan 55 işletmenin büyük bir çoğunluğunu (56,3) 2125 yıl arası ve 25 yıl ve daha fazla faaliyet süresine sahip işletmeler oluşturmaktadır. İşletmelerin \%45,5'inin tekstil işletmeleri olduğu görülmektedir. Katılımc1 işletmelerin hukuki statüleri incelendiğinde \%50,9'unun anonim şirket, \%45,5'inin limited şirket olduğu görülmektedir. İstihdam edilen personel sayıları incelendiğinde işletmelerin \%38,1'inin 51150 kişi arasında, \%27,3 oranları ile 50 kişi ve daha az ve 251 kişi ve daha fazla istihdam oluşturduğu anlaşılmaktadır. İşletmelerin $\% 87,3$ oranı ile ihracat yaptıkları gözlemlenmiştir. Buna ek olarak işletmelerin hangi ülkelere daha fazla ihracat yaptıkları incelendiğinde ise $\% 70,9$ oranı ile $\mathrm{AB}$ üyesi ülkeler en başta yer almaktadır ve bu oranı \%50,9 ile Ortadoğu ülkeleri takip etmektedir. Ayrıca katılımcı işletmelerin ihracat faaliyetlerinin yıllık toplam satışlara oranı ile ilgili elde edilen verilere göre işletmelerin \%32,7'sinin \%51-75 arasında, \%25,5' inin \%76-100 arasında ihracat faaliyetinde bulunduğu anlaşılmaktadır.

Anketi cevaplayan katılımcılardan ve ankete katılan işletmelerden elde edilen verilerin ardından imalat işletmelerinin inovasyon kapasitesi bileşenlerine temel bileşenler analizi uygulanmıştır. $\mathrm{Bu}$ analiz, çok değişkenli bir araştırmada, değişkenlerin birleştirilmesi yoluyla boyut indirgemesi yapılmasını yani değişken sayısının azaltılmasını ve daha az sayıda yeni temel bileşenler oluşturulmasını ifade etmektedir.

Temel bileşenler analizine başlamadan önce, araştırma sonucu elde edilen verilerin bu analize uygun olup olmadığının anlaşılması gereklidir. Bunun için Kaiser-Meyer-Olkin 
(KMO) ve Bartlett Küresellik Testi uygulanmalıdır. Bu testler değişkenler arasındaki ilişkinin gücünü ölçümler. KMO değeri 0 ile 1 arasında değişir (Karaalioğlu, 2015: 5-9). Bartlett testinde $p$ değerinin $0,05^{\prime}$ den küçük olması gereklidir $(\mathrm{p}<0,05)$. Bu ifade değişkenler arasında yüksek korelasyon olduğunu göstermektedir ve p değeri $0,05^{\prime}$ den küçük ise elde ettiğimiz veriler temel bileşenler analizine uygundur (Ersungur vd., 2007: 61).

Tablo 3. Kaiser-Meyer-Olkin Değeri

\begin{tabular}{|c|l|}
\hline KMO Değeri & \multicolumn{1}{|c|}{ Kabul Düzeyi } \\
\hline 0.90 Üzeri & Mükemmel \\
\hline $0.80-0.90$ & Çok İyi \\
\hline $0.70-0.80$ & İyi \\
\hline $0.50-0.70$ & Orta \\
\hline 0.50 Altı & Kabul edilmez \\
\hline
\end{tabular}

Faktör yük değeri, değişkenlerin içinde yer aldıkları bileşenlerle olan ilişkisini açıklayan bir faktördür. Bu değerlerin yüksek olması beklenir. Bir bileşen ile içinde bulunan değişkenler arasında yüksek düzeyde bir ilişki mevcutsa, o değişkenlerin bileşenle birlikte bir yapıyı veya bir faktörü ölçtüğü anlamı çıkarılabilir (Büyüköztürk, 2002: 473). Bileşenin yorumlanması ve adlandırılmasında faktör yükleri dikkate alınır. Değişkenin bileşenle olan korelasyonu $\pm 0,30$ 'dan büyükse, o değişkenin içinde bulunduğu bileşenle anlamlı bir ilişki gösterdiği kabul edilmektedir. Bazı araştırmacılar bu oranın $\pm 0,40$ hatta $\pm 0,50$ olması gerektiğini düşünmektedir. Bir bileşenin ifade edilmesinde 0,30 'dan büyük pozitif faktör yükleri dikkate alındığı gibi negatif faktör yükleri de dikkate alınmaktadır $( \pm 0,30<)$. Buna göre bu bileşende bulunan pozitif faktör yükleri olumlu, negatif faktör yükleri olumsuz ilişki gösterecek şekilde yorumlanmalıdır. Bu şekilde faktörler iki kutuplu olarak incelenebilmektedir (Cengiz vd., 2012: 172).

Tablo 4. Temel Bileşenler Analizi Sonuçları

\begin{tabular}{|c|c|c|}
\hline $\begin{array}{l}\text { İnovasyon } \\
\text { Kapasitesi } \\
\text { Bileşenleri }\end{array}$ & Temel Bileşenler Analizi Bulguları & Açıklama \\
\hline \multirow{2}{*}{$\begin{array}{l}\text { Araştırma- } \\
\text { Gelisstirme } \\
\text { Faaliyetleri }\end{array}$} & $\begin{array}{l}\text { KMO değeri } 0,743 ; \\
\text { Bartlett küresellik testinin anlamlılık } \\
\text { düzeyi ise } 0,000 \text { bulunmuştur. }\end{array}$ & $\begin{array}{l}\text { Bu sonuçlar ölçeğin temel bileşenler } \\
\text { analizine uygun olduğunu } \\
\text { göstermektedir. }\end{array}$ \\
\hline & $\begin{array}{l}\begin{array}{l}\text { Faktör yükleri } \\
\text { bulunmuştur. }\end{array} \\
\end{array}$ & $\begin{array}{l}\text { Bu nedenle hiçbir ifade ölçümden } \\
\text { çlkartılmamıştır. }\end{array}$ \\
\hline \multirow{2}{*}{$\begin{array}{l}\text { İnsan Kaynakları } \\
\text { Yatırımları }\end{array}$} & $\begin{array}{l}\text { KMO değeri } \quad 0,807 ; \\
\text { Bartlett küresellik testinin anlamlılık } \\
\text { düzeyi ise } 0,000 \text { bulunmuştur. }\end{array}$ & $\begin{array}{l}\text { Bu sonuçlar ölçeğin temel bileşenler } \\
\text { analizine uygun olduğunu } \\
\text { göstermektedir. }\end{array}$ \\
\hline & $\begin{array}{l}\text { Faktör yükleri } \pm 0,30^{\prime} \text { dan } \quad \text { yüksek } \\
\text { bulunmuştur. }\end{array}$ & $\begin{array}{l}\text { Bu nedenle hiçbir ifade ölçümden } \\
\text { çlkartılmamıştır. }\end{array}$ \\
\hline \multirow[b]{2}{*}{ İş Birlikleri } & $\begin{array}{l}\text { KMO değeri } 0,781 \text {; } \\
\text { Bartlett küresellik testinin anlamlılık } \\
\text { düzeyi ise } 0,000 \text { bulunmuştur. }\end{array}$ & $\begin{array}{l}\text { Bu sonuçlar ölçeğin temel bileşenler } \\
\text { analizine uygun olduğunu } \\
\text { göstermektedir. }\end{array}$ \\
\hline & $\begin{array}{l}\text { Bu bileşende bulunan "Aynı faaliyet } \\
\text { alanında bulunan (rakip) işletmeler" } \\
\text { değişkeninin faktör yükü } \pm 0,30 \text { 'dan } \\
\text { düşük bulunmuştur. }\end{array}$ & $\begin{array}{l}\text { Bu nedenle bahse konu ifade } \\
\text { ölçümden çlkartılmıştır. }\end{array}$ \\
\hline
\end{tabular}




\begin{tabular}{|c|c|c|}
\hline \multirow{2}{*}{$\begin{array}{c}\text { Fikri Mülkiyet } \\
\text { Hakkı }\end{array}$} & $\begin{array}{l}\text { KMO değeri } \quad 0,719 \text {; } \\
\text { Bartlett küresellik testinin } \\
\text { düzeyi ise } 0,000 \text { bulunmuştur. }\end{array}$ & $\begin{array}{l}\text { Bu sonuçlar ölçeğin temel bileşenler } \\
\text { analizine uygun olduğunu } \\
\text { göstermektedir. }\end{array}$ \\
\hline & $\begin{array}{l}\text { Faktör yükleri } \pm 0,30^{\prime} \text { dan yüksek } \\
\text { bulunmuştur. }\end{array}$ & $\begin{array}{l}\text { Bu nedenle hiçbir ifade ölçümden } \\
\text { çlkartılmamıştır. }\end{array}$ \\
\hline \multirow{2}{*}{$\begin{array}{l}\text { Bilgi İletişim } \\
\text { Teknolojileri }\end{array}$} & $\begin{array}{l}\text { KMO değeri } \quad 0,485 ; \\
\text { Bartlett küresellik testinin anlamlıllk } \\
\text { düzeyi ise } \\
0,086 \text { bulunmuştur. }\end{array}$ & $\begin{array}{l}\text { Bu sonuçlar ölçeğin temel bileşenler } \\
\text { analizine uygun olmadığını } \\
\text { göstermektedir. }\end{array}$ \\
\hline & $\begin{array}{l}\text { Bu bileşenin ilk değişkeni hariç diğer üç } \\
\text { değişkeninin faktör yükleri } \pm 0,30^{\prime} \text { dan } \\
\text { düşük çımıştır. }\end{array}$ & $\begin{array}{l}\text { Bu nedenle bu bileşen analize dahil } \\
\text { edilmemektedir. }\end{array}$ \\
\hline \multirow[b]{2}{*}{$\begin{array}{l}\text { İnovasyon } \\
\text { Finansmanı }\end{array}$} & $\begin{array}{l}\text { KMO değeri } 0,786 ; \\
\text { Bartlett küresellik testinin anlamlılık } \\
\text { düzeyi ise } 0,086 \text { bulunmuştur. }\end{array}$ & $\begin{array}{l}\text { Bu sonuçlar ölçeğin temel bileşenler } \\
\text { analizine uygun olduğunu } \\
\text { göstermektedir. }\end{array}$ \\
\hline & $\begin{array}{l}\mathrm{Bu} \text { bileşende bulunan "İnovasyon } \\
\text { faaliyetine periyodik bütçe ayırma durumu" } \\
\text { ve "Öz kaynaktan yararlanma" } \\
\text { değişkenlerinin faktör yükleri } \pm 0,30 \text { 'dan } \\
\text { düşük bulunmuştur. }\end{array}$ & $\begin{array}{l}\text { Bu nedenle bahse konu ifadeler } \\
\text { ölçümden çlkartılmıştır. }\end{array}$ \\
\hline
\end{tabular}

Sonuç olarak; temel bileşenler analizinden elde edilen verilere göre, Bilgi İletişim Teknolojileri bileşeni analizlere uygun olmadığı için çalışma kapsamında incelemeye tabi tutulmamıştır. Bundan sonra yapılacak bütün analizler de bu bileşenin dışında kalan 5 bileşen üzerinde yapılacaktır.

Çalışma kapsamında uygulanan anket çalışmasının neticesinde ortaya çıan verilerin normal dağılıma uygun olup olmadığını tespit etmek amacıyla Kolmogorow-Simirnov ve ShaphiroWilk testi uygulanmıştır. Testin sonucuna göre, analizi yapılan beş bileşenden sadece bir tanesinin normal dağılım gösterdiği, diğer dört bileşenin normal dağılıma uygun olmadığ gözlemlenmiş ve bu çalışmada parametrik olmayan yöntemler kullanılmıştır.

Araştırma kapsamında incelenen imalat işletmelerinin inovasyon kapasitesi bileşenlerinin her bir ikilisi arasında anlamlı bir ilişkinin bulunup bulunmadığını ve bu ilişkinin pozitif ya da negatif yönlü olup olmadığının test edilebilmesi için Spearman Korelasyon analizi yapılmıştır. Analiz neticesinde elde edilen değerler Tablo 5'de ifade edilmektedir.

Tablo 5. İmalat İşletmelerinin İnovasyon Kapasitesi Bileşenlerinin Spearman Korelasyon Analizi Sonuçları

\begin{tabular}{|c|c|c|c|c|c|c|}
\hline & & $\begin{array}{c}\text { Ar-Ge } \\
\text { Faaliyetleri }\end{array}$ & $\begin{array}{c}\text { İnsan } \\
\text { Kaynakları } \\
\text { Yatırımları } \\
\end{array}$ & İş Birlikleri & $\begin{array}{c}\text { Fikri } \\
\text { Mülkiyet } \\
\text { Hakları } \\
\end{array}$ & $\begin{array}{l}\text { İnovasyon } \\
\text { Finansman }\end{array}$ \\
\hline $\begin{array}{c}\text { Ar-Ge } \\
\text { Faalivetleri }\end{array}$ & $\begin{array}{l}\mathrm{p} \\
\mathrm{r}\end{array}$ & $\begin{array}{c}- \\
1,000\end{array}$ & $\begin{array}{l}0,000 \\
0,519\end{array}$ & $\begin{array}{c}0,004 \\
-0,384\end{array}$ & $\begin{array}{l}0,005 \\
0,374\end{array}$ & $\begin{array}{l}0,068 \\
0,248\end{array}$ \\
\hline $\begin{array}{c}\text { İnsan } \\
\text { Kaynakları } \\
\text { Yatırımları }\end{array}$ & $\mathrm{r}$ & $\begin{array}{l}0,000 \\
0,519\end{array}$ & $\begin{array}{c}- \\
1,000\end{array}$ & 0,001 & $\begin{array}{l}0,419 \\
0,111\end{array}$ & $\begin{array}{l}0,002 \\
0,410\end{array}$ \\
\hline $\begin{array}{c}\text { İş } \\
\text { Birlikleri }\end{array}$ & $\begin{array}{l}\mathrm{p} \\
\mathrm{r}\end{array}$ & $\begin{array}{c}0,004 \\
-0,384 \\
\end{array}$ & $\begin{array}{c}0,001 \\
-0,449 \\
\end{array}$ & $\begin{array}{c}- \\
1,000 \\
\end{array}$ & $\begin{array}{c}0,547 \\
-0,083\end{array}$ & $\begin{array}{r}0,264 \\
-0,153 \\
\end{array}$ \\
\hline Fikri Mülkiyet & $\mathrm{p}$ & 0,005 & 0,419 & 0,547 & - & 0,511 \\
\hline
\end{tabular}




\begin{tabular}{|c|c|c|c|c|c|c|}
\hline Hakları & $\mathrm{r}$ & 0,374 & 0,111 & $-0,083$ & 1,000 & 0,090 \\
\hline İnovasyon & $\mathrm{p}$ & 0,068 & 0,002 & 0,264 & 0,511 & - \\
Finansmanı & $\mathrm{r}$ & 0,248 & 0,410 & $-0,153$ & 0,090 & 1,000 \\
\hline
\end{tabular}

Analiz sonucunda ulaşılan verilere göre; imalat işletmelerinin inovasyon kapasitesi bileşenlerinden ilki olan Ar-Ge faaliyetleri ile İnsan Kaynakları yatırımları bileşenleri arasında anlamlı ve pozitif yönlü orta seviyede bir ilişki vardır. Ar-Ge faaliyetleri ile iş birlikleri bileşenleri arasında anlamlı ve negatif yönlü zayıf bir ilişki, Ar-Ge faaliyetleri ile Fikri Mülkiyet Hakları bileşenleri arasında anlamlı ve pozitif yönlü zayıf bir ilişki, Ar-Ge faaliyetleri ile İnovasyon Finansmanı bileşenleri arasında anlamlı olmayan pozitif yönlü zayıf bir ilişki bulunmaktadır. Sonuç olarak; Ar-Ge faaliyetleri bileşeninin İnsan Kaynakları Yatırımları bileşeni hariç diğer bileşenler ile arasında zayıf bir ilişkinin bulunduğu tespit edilmiştir.

İnsan Kaynakları yatırımları bileşeninin; Ar-Ge faaliyetleri bileşeni ile arasında anlamlı ve pozitif yönlü orta seviyede bir ilişki, İş Birlikleri bileşeni ile arasında anlamlı ve negatif yönlü zayıf bir ilişki, Fikri Mülkiyet Hakları Bileşeni ile arasında anlamlı olmayan pozitif yönlü zayıf bir ilişki, İnovasyon Finansmanı bileşeni ile arasında anlamlı ve pozitif yönlü zayıf bir ilişki bulunmaktadır. Sonuç olarak; İnsan Kaynakları yatırımları bileşeninin Ar-Ge faaliyetleri bileşeni hariç diğer bileşenler ile arasında zayıf bir ilişki bulunmaktadır.

İş Birlikleri bileşeninin; Ar-Ge faaliyetleri bileşeni ile arasında anlamlı ve negatif yönlü zayıf bir ilişki, İnsan Kaynakları bileşeni ile arasında anlamlı ve negatif yönlü zayıf bir ilişki, Fikri Mülkiyet Hakları bileşeni ile arasında anlamlı olmayan negatif yönlü zayıf bir ilişki, İnovasyon finansmanı bileşeni ile arasında anlamlı olmayan negatif yönlü zayıf bir ilişki vardır. Sonuç olarak; İş Birlikleri bileşeni ile diğer bileşenler arasında negatif yönlü zayıf bir ilişki bulunmaktadır.

Fikri Mülkiyet Hakları bileşeninin; Ar-Ge faaliyetleri bileşeni ile arasında anlamlı ve pozitif yönlü zayıf bir ilişki, İnsan Kaynakları yatırımları bileşeni ile arasında anlamlı olmayan pozitif yönlü zayıf bir ilişki, İş Birlikleri bileşeni ile arasında anlamlı olmayan negatif yönlü zayıf bir ilişki, İnovasyon Finansmanı bileşeni ile arasında anlamlı olmayan pozitif yönlü zayıf bir ilişki vardır. Sonuç olarak Fikri Mülkiyet Hakları bileşeninin İş Birlikleri bileşeni hariç diğer bileşenlerle arasında pozitif yönlü bir ilişkisi mevcuttur. Ayrıca Fikri Mülkiyet Hakları bileşeninin diğer bileşenlerle arasında zayıf bir ilişki bulunmaktadır.

İnovasyon Finansmanı bileşeninin; Ar-Ge faaliyetleri bileşeni ile arasında anlamlı olmayan pozitif yönlü zayıf bir ilişki, İnsan Kaynakları yatırımları ile arasında anlamlı ve pozitif yönlü zayıf bir ilişki, İş Birlikleri bileşeni ile arasında anlamlı olmayan negatif yönlü zayıf bir ilişki, Fikri Mülkiyet Hakları ile arasında anlamlı olmayan pozitif yönlü zayıf bir ilişki vardır. Sonuç olarak İnovasyon Finansmanı bileşeni ile İş Birlikleri bileşeni hariç diğer bileşenlerle arasında pozitif yönlü bir ilişki bulunmaktadır. Ayrıca İnovasyon Finansmanı bileşeninin diğer bileşenlerle arasında zayıf bir ilişki bulunmaktadır.

\subsection{Araştırma Bulguları}

Araştırma çerçevesinde test edilmesi istenen hipotezler ve sonuçları aşağıda detaylı bir şekilde ele alınmıştır. 
H1: İmalat işletmelerinin inovasyon kapasitesi bileşenleri ile imalat işletmelerinin faaliyet alanları arasında anlamlı bir farklılık vardır. (Reddedildi)

$\mathrm{Bu}$ ifadeye göre; imalat işletmelerinin inovasyon kapasitesi bileşenleri olarak belirlenen ArGe faaliyetleri, İnsan Kaynakları Yatırımları, İş Birlikleri, Fikri Mülkiyet Hakları ve İnovasyon Finansmanı ile üzerinde araştırma yapılan imalat işlemelerinin faaliyet alanları olarak sıralayabileceğimiz tekstil, makine, mermer, kablo, metal ve kimya sektörleri arasında anlamlı bir farklılık bulunup bulunmadığı hususunda inceleme yapılmıştır. Yapılan analizde imalat işletmelerinin faaliyet alanı ikiden fazla olduğu için parametrik olmayan KruskallWallis testi kullanılmıştır. Test sonucunda elde edilen değerlere Tablo $6^{\prime}$ da yer verilmiştir.

Tablo 6. Hipotez 1'in Kruskall-Wallis Testi Sonuçları

\begin{tabular}{|c|c|c|c|c|c|}
\hline & $\begin{array}{c}\text { Ar-Ge } \\
\text { Faaliyetleri }\end{array}$ & $\begin{array}{c}\text { İnsan Kaynakları } \\
\text { Yatırımları }\end{array}$ & İş Birlikleri & $\begin{array}{c}\text { Fikri Mülkiyet } \\
\text { Hakları }\end{array}$ & $\begin{array}{c}\text { Inovasyon } \\
\text { Finansmanı }\end{array}$ \\
\hline $\boldsymbol{\chi}^{\mathbf{2}}$ & 3,742 & 3,930 & 3,271 & 6,296 & 2,694 \\
$\mathbf{d f}$ & 5 & 5 & 5 & 5 & 5 \\
$\mathbf{p}$ & 0,587 & 0,559 & 0,658 & 0,278 & 0,747 \\
\hline
\end{tabular}

Kruskall-Wallis testi neticesinde incelenen her bir bileşen için elde edilen anlamlılık değeri 0,05 'ten büyük $(0,05<\mathrm{p})$ bir değerdir. Bu sonuçlardan hareketle incelenen her bir bileşenin imalat işletmelerinin faaliyet alanına göre anlamlı bir farklılık göstermediği ifade edilebilir. Başka bir deyişle "imalat işletmelerini inovasyon kapasitesi bileşenleri ile imalat işletmelerinin faaliyet alanları arasında anlamlı bir farklılık vardır" hipotezi reddedilmiştir.

H2: İmalat işletmelerinin inovasyon kapasitesi bileşenleri ile imalat işletmelerinde istihdam edilen personel sayıları arasında anlamlı bir farklılık vardır. (Reddedilmedi)

Hipotez 2'ye göre; imalat işletmelerinin inovasyon kapasitesi bileşenleri olarak belirlenen Ar-Ge faaliyetleri, İnsan Kaynakları Yatırımları, İş Birlikleri, Fikri Mülkiyet Hakları ve İnovasyon Finansmanı ile üzerinde araştırma yapılan imalat işlemelerinde istihdam edilen personel sayısı aralığı olarak "50 kişi ve daha az, 51-150 kişi arası, 151-250 kişi arası, 251 kişi ve daha fazlası" şeklinde sıralayabileceğimiz personel sayıları arasında anlamlı bir farklılık bulunup bulunmadığı hususunda inceleme yapılmıştır. Yapılan analizde imalat işletmelerinde istihdam edilen personel sayıları aralığı ikiden fazla olduğu için parametrik olmayan Kruskall-Wallis testi kullanılmıştır. Test sonucunda elde edilen veriler Tablo 7'de yer almaktadır.

Tablo 7. Hipotez 2'nin Kruskall-Wallis Testi Sonuçları

\begin{tabular}{|l|c|c|c|c|c|}
\hline & $\begin{array}{c}\text { Ar-Ge } \\
\text { Faaliyetleri }\end{array}$ & $\begin{array}{c}\text { İnsan Kaynakları } \\
\text { Yatırımları }\end{array}$ & İş Birlikleri & $\begin{array}{c}\text { Fikri Mülkiyet } \\
\text { Hakları }\end{array}$ & $\begin{array}{c}\text { İnovasyon } \\
\text { Finansmanı }\end{array}$ \\
\hline $\boldsymbol{\chi}^{\mathbf{2}}$ & 3,500 & 15,689 & 3,572 & 5,755 & 3,257 \\
$\mathbf{d f}$ & 4 & 4 & 4 & 4 & 4 \\
$\mathbf{p}$ & 0,478 & 0,003 & 0,467 & 0,218 & 0,516 \\
\hline
\end{tabular}

Kruskall-Wallis testi neticesinde her bir bileşen ayrı ayrı incelenmiştir. İnsan kaynakları yatırımları bileşeni değeri $(0,003)$ hariç diğer dört bileşenden elde edilen verilerin anlamlılık değeri 0,05'ten büyük çıkmıştır. "İnsan Kaynakları Yatırımları" bileşenine dayanarak "İmalat işletmelerinin inovasyon kapasitesi bileşenleri ile İmalat işletmelerinde istihdam edilen personel sayıları arasında anlamlı bir farklılık vardır." hipotezi reddedilememiştir. 
Hipotezde kabul edilen farklılığın kaynağını bulabilmek için Mann-Whitney U testi uygulanmıştır. Uygulanan testin sonuçları aşağıdaki paragraflarda yer almaktadır.

İmalat işletmelerinin Ar-Ge yatırımları bileşeninin istihdam personel sayılarına göre var olan farklılığın kaynağına erişebilmek için uygulanan Mann-Whitney U testi sonucunda elde edilen anlamlılık değerleri Tablo 8'de mevcuttur. Elde edilen veriler incelendiğinde Ar-Ge yatırımları bileşeni için istihdam edilen personel sayıları arasında anlamlı bir farkın olduğu tespit edilememiştir.

Tablo 8. Ar-Ge Faaliyetleri Bileşeni Mann-Whitney U Testi Anlamlılık Değerleri

\begin{tabular}{|l|c|c|c|c|}
\hline & $\begin{array}{c}\text { 50 Kişi ve } \\
\text { Daha Az }\end{array}$ & $\begin{array}{c}\mathbf{5 1 - 1 5 0 ~ K i s ̧ i ~} \\
\text { Arası }\end{array}$ & $\begin{array}{c}\mathbf{1 5 1 - 2 5 0 ~ K i s ̧ i ~} \\
\text { Arası }\end{array}$ & $\begin{array}{c}\text { 250 Kişi ve } \\
\text { Daha Fazla }\end{array}$ \\
\hline $\mathbf{5 0}$ Kişi ve Daha Az & - & 0,448 & 0,545 & 0,306 \\
\hline $\mathbf{5 1 - 1 5 0}$ Kişi Arası & 0,448 & - & 0,823 & 0,488 \\
\hline 151-250 Kişi Arası & 0,545 & 0,823 & - & 0,920 \\
\hline 251 Kişi ve Daha Fazlası & 0,306 & 0,488 & 0,920 & - \\
\hline
\end{tabular}

İmalat işletmelerinin İnsan Kaynakları faaliyetleri bileşeni için istihdam edilen personel sayılarına göre var olan farklılı̆̆ın kaynağına ulaşabilmek amacıyla uygulanan MannWhitney U testi sonucunda elde edilen anlamlılık değerleri Tablo 9'da mevcuttur. Elde edilen veriler incelendiğinde İnsan Kaynakları faaliyetleri bileşeni için istihdam edilen personel sayıları arasında anlamlı bir farkın olduğu tespit edilememiştir.

Tablo 9. İnsan Kaynakları Yatırımları Bileşeni Mann-Whitney U Testi Anlamlılık Değerleri

\begin{tabular}{|l|c|c|c|c|}
\hline & $\begin{array}{c}\mathbf{5 0} \text { Kişi ve Daha } \\
\mathbf{A z}\end{array}$ & $\begin{array}{c}\mathbf{5 1 - 1 5 0} \text { Kişi } \\
\text { Arası }\end{array}$ & $\begin{array}{c}\mathbf{1 5 1 - 2 5 0} \text { Kişi } \\
\text { Arası }\end{array}$ & $\begin{array}{c}\text { 250 Kişi ve } \\
\text { Daha Fazla }\end{array}$ \\
\hline $\mathbf{5 0}$ Kişi ve Daha Az & - & 0,187 & 0,725 & 0,262 \\
\hline $\mathbf{5 1 - 1 5 0}$ Kişi Arası & 0,187 & - & 0,655 & 0,949 \\
\hline 151-250 Kişi Arası & 0,725 & 0,655 & - & 0,763 \\
\hline 251 Kişi ve Daha Fazlası & 0,262 & 0,949 & 0,763 & - \\
\hline
\end{tabular}

İmalat işletmelerinin İş Birlikleri bileşeninin istihdam edilen personel sayılarına göre var olan farklılığın kaynağına erişebilmek için uygulanan Mann-Whitney U testi sonucunda elde edilen anlamlılık değerleri Tablo 10'da mevcuttur. Bu veriler 0,05 anlamlılık düzeyinde; 50 kişi ve daha az ile 51-150 kişi arası $(\mathrm{p}=0,020<0,050), 250$ kişi ve daha fazlası $(0,011<0,050)$ arasında anlamlı bir farklılığın olduğu belirlenmiştir.

Tablo 10. İş Birlikleri Bileşeni Mann-Whitney U Testi Anlamlılık Değerleri

\begin{tabular}{|l|c|c|c|c|}
\hline & $\begin{array}{c}\text { 50 Kişi ve } \\
\text { Daha Az }\end{array}$ & $\begin{array}{c}\mathbf{5 1 - 1 5 0 ~ K i s ̧ i ~} \\
\text { Arası }\end{array}$ & $\begin{array}{c}\mathbf{1 5 1 - 2 5 0 ~ K i s ̧ i ~} \\
\text { Arası }\end{array}$ & $\begin{array}{c}\text { 250 Kişi ve } \\
\text { Daha Fazla }\end{array}$ \\
\hline $\mathbf{5 0}$ Kişi ve Daha Az & - & 0,020 & 0,450 & 0,011 \\
\hline $\mathbf{5 1 - 1 5 0}$ Kişi Arası & 0,020 & - & 0,324 & 0,578 \\
\hline 151-250 Kişi Arası & 0,450 & 0,324 & - & 0,202 \\
\hline 251 Kişi ve Daha Fazlası & 0,011 & 0,578 & 0,202 & - \\
\hline
\end{tabular}

İmalat işletmelerinin İnovasyon Finansmanı bileşeni için istihdam edilen personel sayılarına göre var olan farklılığın kaynağına ulaşabilmek amacıyla uygulanan Mann-Whitney U testi sonucunda elde edilen anlamlılık değerleri Tablo 11'de mevcuttur. Elde edilen veriler 
incelendiğinde İnovasyon Finansmanı bileşeni için istihdam edilen personel sayıları arasında anlamlı bir farkın olduğu tespit edilememiştir.

Tablo 11. İnovasyon Finansmanı Bileşeni Mann-Whitney U Testi Anlamlılık Değerleri

\begin{tabular}{|l|c|c|c|c|}
\hline & $\begin{array}{c}\mathbf{5 0} \text { Kişi ve } \\
\text { Daha Az }\end{array}$ & $\begin{array}{c}\mathbf{5 1 - 1 5 0 ~ K i s ̧ i ~} \\
\text { Aras1 }\end{array}$ & $\begin{array}{c}\mathbf{1 5 1 - 2 5 0 ~ K i s ̧ i ~} \\
\text { Aras1 }\end{array}$ & $\begin{array}{c}\text { 250 Kişi ve } \\
\text { Daha Fazla }\end{array}$ \\
\hline $\mathbf{5 0}$ Kişi ve Daha Az & - & 0,271 & 0,086 & 0,117 \\
\hline $\mathbf{5 1 - 1 5 0}$ Kişi Arası & 0,271 & - & 0,576 & 0,711 \\
\hline $\mathbf{1 5 1 - 2 5 0}$ Kişi Arası & 0,086 & 0,576 & - & 0,880 \\
\hline 251 Kişi ve Daha Fazlası & 0,117 & 0,711 & 0,880 & - \\
\hline
\end{tabular}

Hipotezin test edilmesi süresince farklılığın kaynağına ulaşabilmek için uygulanan MannWhitney $U$ Testi sonucunda sadece iş birliği bileşeninde istihdam edilen personel sayıları için "50 kişi ve daha az ile 51-150 kişi arası", "50 kişi ve daha az ile 250 kişi ve daha fazlası" arasında anlamlı bir farklılığın olduğu tespit edilmiştir.

\section{SONUÇ}

Sonuç olarak; Denizli'de faaliyet gösteren imalat işletmelerinin inovasyonu ortaya koyma ve inovasyon kapasitesini geliştirme ve kullanma konularında beklenilen seviyede olmadığ görülmüştür. Ancak işletmelerin inovasyonun ortaya çıkarılması, inovasyon konusunda farkındalığın olması, inovasyon kapasitelerinin arttırılması hususunda gerekli adımların atılması için istekli ve çözüm odaklı oldukları gözlemlenmiştir.

Denizli'de faaliyet gösteren imalat işletmelerinin inovasyon kapasitesi ile ilgili bazı pürüzleri ortadan kaldırabilmeleri için şu çözümler önerilebilir;

İşletmelerin Ar-Ge faaliyetleri çalışmalarında, Ar-Ge çalışanı bulundurma ve Ar-Ge için çalışma yapan bir departman kurmaları bu konu üzerinde gerekli farkındalığın oluştuğunu bizlere göstermektedir. Bunun yanında Ar-Ge çalışmaları için dışarıdan hizmet alımında bulunma faaliyetleri, Ar-Ge çalışanı veya departmanı bulundurma durumlarının biraz gerisinde kaldığı tespit edilmiştir. İşletmelerin dış kaynaklardan hizmet satın alımı gerçekleştirmesi hususunda daha özenli bir çalışmanın yapılması, dışarıdan farklı bir gözle faaliyetlerinin incelenmesi ve yeni sayılabilecek bir bakış açısının kazandırılması işletmelerin inovatif olma yolunda dikkat etmesi gereken önemli adımlardan bir tanesidir. Bu sayede daha farklı ve daha yararlı sonuçlar elde edilmesine olanak sağlanacaktır.

İşletmelerin insan kaynakları çalışmalarında dış kaynaklardan inovasyon danışmanlığı alması, çalışanların inovasyon konusunda bilinçlenmesi ve farkındalıklarının artması ve işletmenin inovatifliğini artırabilecek faaliyetlerde bulunabilmesi adına önemli bir adım olacaktır. Elde edilen verilerde işletmelerin şimdiye kadar dış kaynaklardan danışmanlık alma isteği düzeyinin düşük, gelecekte dış kaynaklardan inovasyon danışmanlığı alma isteğinin orta seviyede çıkması, bu konu için daha çok çalışma yapılması gerektiğinin altını çizmektedir.

İşletmelerin inovatif faaliyetlerde bulunmak için iş birliği yapma durumu incelendiğinde, farklı şekillerde iş birliği faaliyetlerinin var olması dikkati çekmektedir. İlk aşamada çalışmaya katılan işletmelerin yarıdan fazlasının iş birliği yaptığına ve bu faaliyetlere açık olduğuna dair olumlu bilgiler elde edilmiştir. Ancak bu faaliyetler ağırlıklı olarak makine, teçhizat, malzeme veya yazılım sağlayıcılarla yapılan tedarikçi iş birliği ile sınırlı kalmıştır. 
Bunun yanında özel ve kamu araştırma kuruluşları, danışmanlık şirketleri, üniversitelerin tekno-kentleri ile gerçekleştirilen faaliyetlerin geri planda kaldığı tespit edilmiştir. İnovasyon fikrinin ortaya çıkarılmasından nihai sonucun elde edilmesine kadar olan süreçte bu kuruluşlarla gerçekleştirilen aktif iş birliği faaliyetleri işletmelerin inovatif bakış açısına sahip olması, bu konuda kendilerini geliştirmeleri ve inovasyon kapasitesilerini artırmaları konusunda yararlı sonuçlar elde edilmesini sağlayacaktır.

İşletmelerin fikri mülkiyet hakları ile ilgili markalaşma, patent sahibi olma, hizmet veya ürün tescil ettirme ve endüstriyel tasarım belgesine sahip olma çalışmalarına ağırlık vermeleri olumlu sonuçlar meydana getirecektir. Çalışma kapsamında işletmelerin marka ve patent sahibi olma ya da hizmet/ürün tescil ettirme konularında aktif yer almamaları, bu konuya önem verilmediği sonucunu ortaya çıkarmaktadır. Bunun sebebi olarak, görüşme yapılan işletmelerin sektör fark etmeksizin ağırlıklı olarak fason üretim yapması gösterilebilir. İşletmeler ne kadar kaliteli ve yenilikçi ürün veya hizmet üretim faaliyetinde bulunsalar da belli bir marka ortaya koyma çalışmalarında bulunmamaları işletmeleri olumsuz etkilemekte ve hem ulusal hem de uluslararası rekabet ortaminda rakiplerinden geri kalmalarına neden olmaktadır. İşletmelerin dünya pazarlarında yer sahibi olma ve ticaret hacmini artırma bakımından fikri mülkiyet haklarına sahip olma ve koruma çalışmaları gün geçtikçe önemli hale gelmiştir.

İşletmelerin hızla gelişen teknoloji ile müşterilerine ulaşma teknikleri de değişiklik göstermektedir. Günümüzde klasik ticaret çalışmalarının yanında e-ticaret faaliyetleri de giderek artan öneme sahiptir. Araştırma kapsamında, işletmelerden bilgi iletişim teknolojilerini kullanma ve benimseme konusunda elde edilen veriler incelendiğinde eticaret faaliyetlerinin diğer bilgi iletişim teknolojileri çalışmalarından daha geride olduğu sonucuna varılmıştır. Müşteriler, yüz yüze iletişimin yanı sıra, dünyanın neresinde olurlarsa olsunlar istedikleri hizmetin sunulması ve bu ürün veya hizmetlere kolaylıkla ulaşabilmek hususunda e-ticaret hizmetlerini takip etmektedirler. Bu nedenle müşterilere kolaylıkla ulaşabilmek, istek ve arzularını tatmin edebilmek ve işletmelerin kendileri açısından da tercih edilebilirliklerini artırmak amacıyla e-ticaret faaliyetlerine de gereken özeni göstermeleri gerekmektedir.

İşletmelerin inovasyon finansmanı ile ilgili durumu incelendiğinde, inovasyon çalışmalarında kullanmak üzere birçok özel ve kamu kuruluşunun sağladığı destekler dikkati çekmektedir. Ancak çalışmaya katılan işletmelerin, inovasyonun ortaya çıkartılabilmesi için gerekli olan maddi kaynağı kendi öz kaynaklarından temin ettiği sonucuna varılmış ve çeşitli özel ve kamu kuruluşlarının inovasyon için sağladığ desteklerden yararlanamadığı gözlemlenmiştir. Bunun sebebi ise işletmelerin sağlanan desteklerden haberdar olmaması, destek kuruluşlarına sunulan projelerin desteğe uygun bulunmaması, sağlanan desteğin projeyi finanse edecek nitelikte olmaması ve gereksiz bürokratik engeller nedeni ile işletmelerin kendi kaynaklarını kullanmayı tercih etmeleri şeklinde ifade edilmiştir. Bu sebeplerin ortadan kaldırılması ve teşviklerin daha makul bir şekilde yaygınlaştırılması neticesinde işletmeler inovatif faaliyette bulunma konusunda hem daha istekli olacaklar hem de daha verimli sonuçlar elde edeceklerdir.

Araştırma kapsamında elde edilen veriler Denizli ili, Pamukkale ve Merkezefendi ilçelerinde faaliyet gösteren ve anket çalışmasına dahil olan 55 imalat işletmesi ile sınırlı kalmıştır. 
Sonradan yapılmak istenilen çalışmalarda imalat işletmelerinin inovasyon kapasitesi konusunun daha geniş bir çerçevede farklı illerde veya farklı bölgelerde uygulanması, elde edilen verilerin daha güvenilir ve geçerli olmasına olanak sağlayacaktır. Daha geniş bir çalışma yapılmasının neticesinde ise daha genel sonuçlar elde edilebilecektir.

\section{KAYNAKÇA}

Akman, G. \& Cengiz Y. (2008). Innovate Capability, Innovation Strategy and Market Orientation: An Empirical Analysis in Turkish Software Industry, International Journal of Innovation Management, 12(1), 69-111.

Büyüköztürk, Ş. (2002). Faktör Analizi: Temel Kavramlar ve Ölçek Geliştirmede Kullanımı, Kuram ve Uygulamada Ĕ̆itim Yönetimi, (32), 470-483.

Cengiz, D., Erim H. (2012). Faktör Analizi ile Ağırlıklandırarak Yetkinlik ve Envanterinin Değerlendirmesi ve Performans Değerlendirmeye Etkisi, İstanbul Ticaret Üniversitesi Sosyal Bilimler Dergisi, (21), 165-178.

Drucker, P. (1998). The Disipline of Innovation, Harvard Business Review, NovemberDecember.

Ecevitsatı, Z., Özlem I. (2011). İnovasyon ve Stratejik Yönetim Sinerjisi: Stratejik İnovasyon, Celal Bayar Üniversitesi Sosyal Bilimler Dergisi, 9(2), 538-559.

Elçi, Ş. (2006). İnovasyon: Kalkınmanın ve Rekabetin Anahtarı, Genişletilmiş Baskı, İnomer Rekabet ve Kalkınma.

Ersungur, Ş. M., Alaattin K., Özgür P. (2007). Türkiye'de Bölgelerin Sosyo-Ekonomik Gelişmişlik Sıralaması: Temel Bileşenler Analizi, İktisadi ve İdari Bilimler Dergisi, 21(2), $55-66$.

Karaalioğlu, Z. (2015). SPSS'de Output Analizi. İstanbul.

Karaveg, C. (2013). Factors Affecting the Innovation Capacity of Thai Textile and Clothing Industries in Thailand, IRACST - International Journal of Research in Management and Technology, 3(1), Thailand.

Lopez-Claros, A., Yasmina N. M. (2010). The Innovation Capacity Index: Factors, Policies, and Institutions Driving Country Innovation, The Innovation for Development Report, 365 .

Marcella De Martino, Fabio Magnotti, (2017) "The innovation capacity of small food firms in Italy",European Journal of Innovation Management, https://doi.org/10.1108/EJIM-04-20170041

Naktiyok, A. (2007). Yenilik Yönelimi ve Örgütsel Faktörler, İktisadi ve İdari Bilimler Dergisi, 21(2).

Oecd/Avrupa Birliği (2005). Oslo Kılavuzu: Yenilik Verilerinin Toplanması ve Yorumlanması İçin Ilkeler, 3. Baskı, Tübitak.

Roman, J. A. Ma., Javier G., Juan A. T. (2011). Analysis of Innovation In SMEs Using An Innovate Capability-based Non-linear Model: A Study In The Province of Seville (Spain), Technovation 31, 459-475. 